\title{
Design, Synthesis, Docking Study and Antiplatelet Evaluation of New Thiosemicarbazide Derivatives,Derived From Captopril
}

\section{HIBA NAJEH AL-SAAD ${ }^{1}$, AMMAR ABDUL RAZZAK MAHMOOD ${ }^{2 *}$ and REDHA I. AL-BAYATI ${ }^{3}$}

\author{
${ }^{1}$ Department of Pharmaceutical Chemistry, Basrah University, Basrah-Iraq. \\ 2Department of Pharmaceutical Chemistry, College of Pharmacy-University of Baghdad, \\ Baghdad, Bab-Al-Mouadam-10001-Iraq. \\ ${ }^{3}$ Department of Chemistry, College of Science, Al-Mustansirya University, Baghdad, 10001, Iraq. \\ ${ }^{*}$ Corresponding author E-mail: kubbaammar1963@gmail.com
}

http://dx.doi.org/10.13005/ojc/350246

(Received: December 26, 2018; Accepted: March 15, 2019)

\begin{abstract}
A series of thiosemicarbazide derivatives of captopril, a well-known angiotensin-converting enzyme inhibitor ACEI, have been synthesized by reaction of hydrazide of captopril with different phenylisothiocyanate substituents. The synthesized compounds were characterized using FTIR, ${ }^{1} \mathrm{HNMR}$ and CHNS analysis. The final derivatives were tested for antiplatelet activity using multiplate analyzer and adenosine diphosphate (ADP), arachidonic acid (AA), and collagen, as platelet aggregation inducers. Among tested compounds, derivative 7 and 10 were the most potent inhibitors of platelet aggregation induced by arachidonic acid, with percent inhibition $(97.14 \pm 0$ and $95.71 \pm 2.02)$ and $\mathrm{IC}_{50}(2.7$ and $1.21 \mu \mathrm{g} / \mathrm{ml})$, respectively. Molecular docking study was performed using purino receptor $\mathrm{P}_{2} \mathrm{Y}_{12}, \mathrm{COX}-1$, and glycoprotein IlbVllla as the target protein, compound 7 has a potential to become as a lead molecule for COX-1 inhibitor with binding energy $(-10.67) \mathrm{Kcal} / \mathrm{mol}$. Also, compound 6 was found as the best inhibitor for the glycoprotein Ila/lllb with percent inhibition $(83.9 \pm 2.8)$, and binding energy $(-10.05) \mathrm{Kcal} / \mathrm{mol}$.
\end{abstract}

Keywords: Captopril, ACEI, Antiplatelet, Thiosemicarbazide, COX-1.

\section{INTRODUCTION}

Thrombosis is a pathological clot takes a vital role in many diseases as deep venous thrombosis, myocardial infarction, and stroke ${ }^{1,2}$. Haematosis refer to the maintenance of blood fluidity and prevents it lose of after vascular injury ${ }^{3}$. Platelet and coagulation factors have a leading role in haemostatic and thrombotic processes, which are involved in thrombus formation and to avoid haemorrhage through stimulation and stabilization of thrombin ${ }^{4,5}$. One of the rational approaches for prevents and treatment of the cardiovascular diseases associated with thrombosis is using anticoagulant and antiplatelet drugs.

This is an Open Access article licensed under a Creative Commons license: Attribution 4.0 International (CC- BY). Published by Oriental Scientific Publishing Company @ 2018 
The coagulation system consists of intrinsic and extrinsic pathways the typical final mediated of this system is thrombin, that trigger production of factors (V, VIII, and IX), activation of platelet and cleavage of fibrinogen to fibrin where it remains active after binds to fibrin ${ }^{6}$, many approaches for protection or treatment of thromboembolic events depend on inhibition of thrombin formation or block its activity. While the main antiplatelet mechanisms are; first, cycloxygenase-1 (COX-1) inhibitor, likes aspirin, by inhibition of (COX-1), aspirin will reduce the extent of thromboxane A2 formation, and consequently the aggregation of platelets ${ }^{7}$, like most NSAIDs, its use is associated with the induce of asthma, gastrointestinal (GIT) disorder, and reduce the number of white cells and platelet ${ }^{8}$. Second, adenosine diphosphate (ADP) antagonist as clopidogrel, which acts by preventing (ADP) stimulates platelet's purinergic receptor $P_{2} Y_{12}$, it has more considerable role in treatment of pathological conditions associated with high platelet reactivity, as acute coronary syndrome (ACS), and coronary artery disease (CAD), also its uses associated with GIT adverse effect ${ }^{9}$. Third, platelet membrane glycoprotein Ilb/Illa receptor inhibitor as tirofiban that is used in treating coronary artery bypass grafting (CABG), and atherectomy, bleeding is the significant adverse effect ${ }^{10}$.

Thiosemicarbazide and its derivatives have attracted significant attention as versatile reagents in synthetic organic chemistry. It shows a broad spectrum of biological activities, such as antifungal, antibacterial, anticonvulsant ${ }^{11}$, antioxidant ${ }^{12}$, antitumor ${ }^{13}$. Anti-inflammatory and antithrombotic activity of synthetic compounds contain thiosemicarbazide moiety, make it an attractive unit in developing a new compound for cardiovascular activity ${ }^{14,15}$.

The aim of this study, is to synthesize a series of new captopril derivatives, a first oral active angiotensin converting enzyme inhibitor (ACEI) drug, containing thiosemicarbazide moiety, for enhancing the cardiovascular activity of captopril, and avoid the main limitations that associated with common anticoagulant, and antiplatelet drugs.

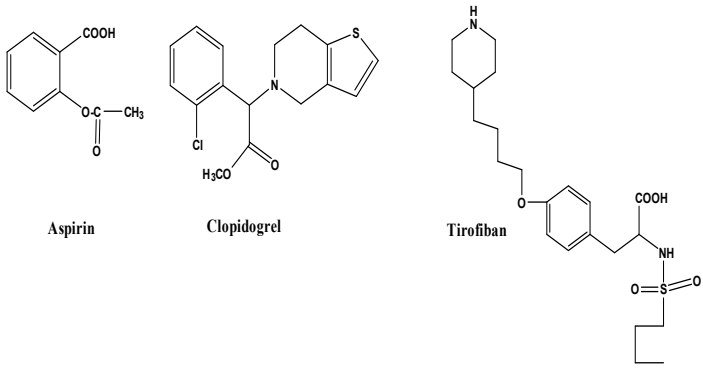

Fig. 1. Chemical structures of some antiplatelet drugs

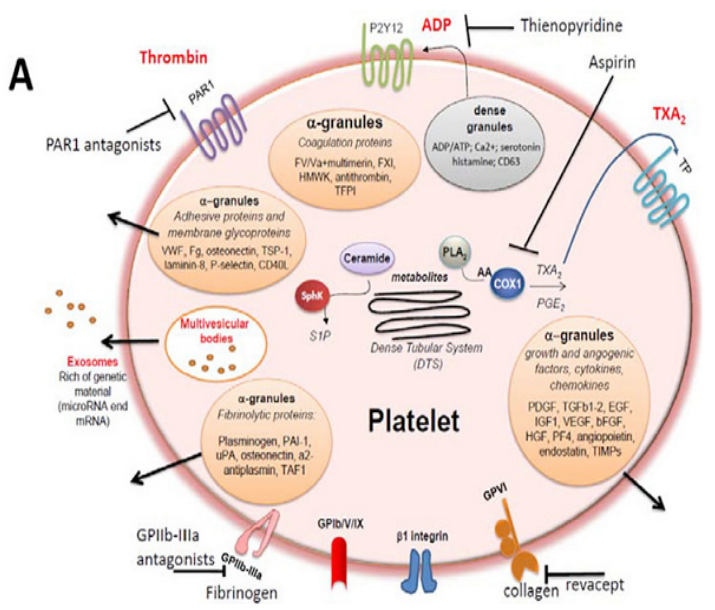

Fig. 2. Platelet receptor-ligand interaction ${ }^{16}$

\section{MATERIALS AND METHODS}

All reagents and anhydrous solvents were used as received from the commercial suppliers, (Sigma-Aldrich, Munich, Germany, BDH, Pool Dorset, England and Fluka, Newport News, USA). Captopril as $(s, s)$ isomer was purchased from Sigma-Aldrich (Shanghai, China). Melting points were determined by the capillary method using Electrothermal IA9000, Essex, UK and they are uncorrected. Thin layer chromatography (TLC) was run on silica gel (60) F254 Merck (Germany), exposed to UV254 nm light, and the eluent used is n-hexane: ethyl acetate (1:1) for compounds $(1,2)$ and $(5-10)$, and chloroform: methanol (1:1) for compounds (3) and (4), to check the purity of the compounds, as well as, monitoring the progress of reactions. FT-IR spectra were recorded by using a Shimadzu model (Kyoto, Japan) spectrophotometer on $\mathrm{KBr}$ disk, $\left(\mathrm{v}=\mathrm{cm}^{-1}\right)$.CHNS microanalysis was done by using a Euro EA3000 elemental analyzer (Carlo Erba, Milan, Italy). ${ }^{1} \mathrm{HNMR}$ spectra were recorded on Inova model Ultra shield $500 \mathrm{MHz}$, at (Tehran University, Iran), using tetramethylsilane 
(TMS) as an internal standard. The chemical shift was expressed as $\left(\delta=\right.$ ppm), DMSO- $d_{6}$ was used as a solvent.

\section{Chemical Synthesis}

Chemical synthesis of all new derivatives is depicted in scheme 1.

\section{Synthesis of methyl 1-(3-mercapto-2-methylpropanoyl) pyrrolidine-2-carboxylate (1): ${ }^{17,18}$}

To $(9.21 \mathrm{mmol}, 2.0 \mathrm{~g})$ of cold captopril solution in $(20 \mathrm{ml})$ methanol, $(9.21 \mathrm{mmol}, 1.8 \mathrm{ml})$ of thionyl chloride $\left(\mathrm{SOCl}_{2}\right)$, was added via dropping funnel, over $30 \mathrm{~min}$. The temperature was maintained at $0^{\circ} \mathrm{C}$ for $1 \mathrm{~h}$. The mixture was stirred for $2 \mathrm{~h}$, at $\mathrm{r}$. $\mathrm{t}$ and then, $4 \mathrm{~h}$ at $50-60^{\circ} \mathrm{C}$. Excess of solvent and $\left(\mathrm{SOCl}_{2}\right)$ was removed by rotary evaporator. The product was re-dissolved in $(20 \mathrm{ml})$ ethyl acetate, and extracted with $5 \%$ sodium bicarbonate and water $(3 \times 20 \mathrm{ml})$, respectively. The organic layer was dried over anhydrous $\mathrm{MgSO}_{4}$, and left the solvent to evaporate.

Colourless oil, yield $50 \%$., B.P $75^{\circ} \mathrm{C}, \mathrm{R}_{f}$ $=0.5$, IR $\left(\mathrm{KBr}\right.$ disc, $\left.\mathrm{v}=\mathrm{cm}^{-1}\right): 2972.31$ and 2875.86 $(\mathrm{CH})$ str of aliph. $\mathrm{CH}_{2} \& \mathrm{CH}_{3} ; 2549.89(\mathrm{SH})$ str of thiol; $1732.08(\mathrm{C}=\mathrm{O})$ str of ester; $1639.49(\mathrm{C}=\mathrm{O}) \mathrm{str}$ of amide of pyrrolidine; 1172.08 asym str (C-O-C); 1043.43 sym $(\mathrm{C}-\mathrm{O}-\mathrm{C})$ str of $\mathrm{OCH}_{3}$.

\section{Synthesis of ethyl 1-(3-(ethylthio)-2-methylpropanoyl) pyrrolidine-2-carboxylate (2) ${ }^{19-21}$}

To a solution of captopril $(9.20 \mathrm{mmol}, 2.0 \mathrm{~g})$ in $(25 \mathrm{ml})$ of dry acetone, $(18.40 \mathrm{mmol}, 2.54 \mathrm{~g})$ of anhydrous $\mathrm{K}_{2} \mathrm{CO}_{3}$ was added. The mixture stirred for $1 \mathrm{~h}$ at r.t. Then (18.4 mmol, $5.6 \mathrm{ml}$,) of ethyl iodide $\left(\mathrm{C}_{2} \mathrm{H}_{5}-\mathrm{I}\right)$ was added throughout $15 \mathrm{~min}$. The reaction was heated at $50^{\circ} \mathrm{C}$ for 24 hour. Under reduced pressure; an excess of solvent was removed after filtration, then re-dissolved the product in $(20 \mathrm{ml})$ ethyl acetate, and extracted it with $5 \% \mathrm{NaHCO}_{3}$ and water $(3 \times 20 \mathrm{ml})$ respectively, then dried over anhydrous $\mathrm{MgSO}_{4}$, and left it overnight.

Yellow oily, yield $72 \%$, B.P $79^{\circ} \mathrm{C}, \mathrm{R}_{f}=0.8$, IR $\left(\mathrm{KBr}\right.$ disc, $\left.\mathrm{v}=\mathrm{Cm}^{-1}\right): 2974.23,2931.18$ and 2873.94 (C-H) str. of aliph. $\mathrm{CH}_{2}$ \& $\mathrm{CH}_{3} ; 1728.22(\mathrm{C}=\mathrm{O})$ str. of ester; $1645.28(\mathrm{C}=\mathrm{O})$ str of amide pyrrolidine; 1028.06 (C-O-C) str of ester.
General method for the synthesis of 1-(3-mercapto2-methylpropanoyl)pyrrolidine-2-carbohydrazide (3); and1-(3-(ethylthio)-2-methylpropanoyl) pyrrolidine-2-carbohydrazide (4).22,23

To $(9.0 \mathrm{mmol}),(0.18 \mathrm{~g})$ of compound 1 or $(0.20 \mathrm{~g})$ of 2 , respectively, in $(20 \mathrm{ml})$ of absolute $\mathrm{EtOH}$, $(27 \mathrm{mmol}, 0.88 \mathrm{ml})$ of hydrazine hydrate was added slowly, with stirring for $2 \mathrm{~h}$ at r.t then, the mixture was refluxed for $6 \mathrm{~h}$. The solvent was removed under reduced pressure, the white precipitate formed, was recrystallized from methanol: diethyl ether (1:2).

\section{Compound 3}

White powder, yield $72 \%$, m.p: $160-162^{\circ} \mathrm{C}$, $\mathrm{R}_{f}=0.9$. IR $\left(\mathrm{KBr}\right.$ disc, $\left(\mathrm{v}=\mathrm{cm}^{-1}\right): 3506.59$ and 3460.3 $(\mathrm{NH})$ str of prim. amine; $3332.99(\mathrm{NH})$ str of prim. amide; 2970.38, 2947.23 and $2873.94(\mathrm{C}-\mathrm{H})$ str of aliph. $\mathrm{CH}_{2} \& \mathrm{CH}_{3} ; 2592.33$ str of $(\mathrm{SH}) ; 1662$ $(\mathrm{C}=\mathrm{O})$ str of amide hydrazide; $1635.64(\mathrm{C}=\mathrm{O})$ str amide of pyrrolidine. Elemental analysis: Calcd. for $\left(\mathrm{C}_{9} \mathrm{H}_{17} \mathrm{~N}_{3} \mathrm{O}_{2} \mathrm{~S}\right)$ : C: 46.73; $\mathrm{H}: 7.41 ; \mathrm{N}: 18.17$; $\mathrm{S}$ : 13.86. Found: C: 46.20; H: 7.32; N: 17.82; S: 13.11. ${ }^{1} \mathrm{HNMR}\left(500 \mathrm{MHz}, \mathrm{DMSO}-\mathrm{d}_{6}, \delta=\mathrm{ppm}\right) ; 9.22(1 \mathrm{H}, \mathrm{s}$, $\mathrm{NH}$-minor); 8.91 (1H, NH-major); 4.21 (2H, brs, $\mathrm{NH}_{2}$ ); $3.55\left(2 \mathrm{H}, \mathrm{m}, \mathrm{CH}_{2}\right.$-pyrrolidine); 2.45-2.96 (3H, m, $\mathrm{CH}_{2}$ and $\mathrm{CH}$ aliph.); $1.83\left(3 \mathrm{H}, \mathrm{m}, \mathrm{CH}_{2}\right.$ and $\mathrm{CH}$-pyrrolidine); $1.04\left(3 \mathrm{H}, \mathrm{d}, \mathrm{CH}_{3}\right)$.

\section{Compound 4}

White powder, yield $65 \%$, m. p: $175-177^{\circ} \mathrm{C}$, $\mathrm{R}_{f}=0.85$, IR $\left(\mathrm{KBr}\right.$ disc, $\left.\mathrm{v}=\mathrm{cm}^{-1}\right): 3305.99$ and 3213.41 $(\mathrm{NH})$ str of prim. amine; $3028.24(\mathrm{NH})$ str of prim. amide; 2970.38, 2931.8 and $2873.94(\mathrm{C}-\mathrm{H})$ str of aliph. $\mathrm{CH}_{2}$ and $\mathrm{CH}_{3} ; 1693.3(\mathrm{C}=\mathrm{O})$ str of amide hydrazide; $1647.21(\mathrm{C}=\mathrm{O})$ str amide of pryrrolidine. Elemental analysis: calcd. for $\left(\mathrm{C}_{11} \mathrm{H}_{21} \mathrm{~N}_{3} \mathrm{O}_{2} \mathrm{~S}\right)$ : C: 50.94; H: 8.16; N: 16.20; S: 12.36. Found: C: 50.60; H: 7.91; N: 16.11; S: 11.88. 'HNMR (500MHz, CD ${ }_{3} \mathrm{OD}$, $\delta=$ ppm); 4.38 (1H, dd, CH-pyrrolidine); $3.73(3 \mathrm{H}, \mathrm{m}$, $\mathrm{CH}_{2}$ and $\mathrm{CH}$-pyrrolidine); 2.61-3.12 $\left(5 \mathrm{H}, \mathrm{m}, 2\left(\mathrm{CH}_{2}\right)\right.$ and $\mathrm{CH}$-aliph.), 1.70-2.25 (3H, m, $\mathrm{CH}_{2}$ and $\mathrm{CH}$ pyrrolidine); 1.19-1.25 $\left(6 \mathrm{H}, \mathrm{m}, 2 \mathrm{CH}_{3}\right)$.

General method for the synthesis of non-protected I free (SH)- thiosemicarbazide captopril derivatives $(5-8)$, and synthesis of ethyl protected (SH) thiosemicarbazide captopril derivatives (9-10). ${ }^{24}$

To $(1.90 \mathrm{mmol}),(0.40 \mathrm{~g})$ of compound 3 or $(0.50 \mathrm{~g})$ of 4 , in $(20 \mathrm{ml})$ absolute methanol, $(1.90$ $\mathrm{mmol}$ ) of phenylisothiocyanate derivatives each was added as dropwise with stirring. The reaction 
temperature was maintained at $40^{\circ}-50^{\circ} \mathrm{C}$, and it was monitored by TLC for 4-6 h, using eluent, $n$-hexane: ethyl acetate (1:1). The solid precipitate was filtrated, recrystallized with ethyl acetate, and dried in a vacuum desiccator.

\section{Compound 5: 2-((3-mercapto-2-methylpropanoyl)} prolyl)-N-phenylhydrazine-1- carbothioamide White powder, yield $45 \%$, m.p: $180-185^{\circ} \mathrm{C}$, $\mathrm{R}_{f}=0.21$, IR $\left(\mathrm{KBr}\right.$ disc, $\left.\mathrm{v}=\mathrm{cm}^{-1}\right): 3248.13$ br. $(\mathrm{N}-\mathrm{H})$ str of $\left(1^{\text {st }}\right.$ amide, $2^{\text {nd }}$ amine and $\mathrm{NH}$ adjacent to thiocarbonyl); 3055.24 $\mathrm{Ar}(\mathrm{CH})$ str; 2974.23, 2951.09 and $2873.94(\mathrm{C}-\mathrm{H})$ str of aliph. $\mathrm{CH}_{2} \& \mathrm{CH}_{3} ; 2592.33$ str of $(\mathrm{SH}) ; 1693.5(\mathrm{C}=\mathrm{O})$ str of amide hydrazide; 1616.35( $\mathrm{C}=\mathrm{O})$ str of amide pyrrolidine; 1546.91, 1500.62 and $1446.61 \operatorname{Ar}(\mathrm{C}=\mathrm{C})$ str; 1184.29 str of $(\mathrm{C}=\mathrm{S})$. Elemental analysis: Calcd. for $\left(\mathrm{C}_{16} \mathrm{H}_{22} \mathrm{~N}_{4} \mathrm{O}_{2} \mathrm{~S}_{2}\right)$ C: 52.43; H: 6.05; N: 15.29; S: 17.50. Found: C: 52.22; H: 5.77; N: 15.15; S: 17.24. ${ }^{1} \mathrm{HNMR}(500 \mathrm{MHz}$, DMSO- $\left._{\mathrm{d} 6}, \delta=\mathrm{ppm}\right) ; 10.38(1 \mathrm{H}, \mathrm{s},(\mathrm{O}=\mathrm{C})-\mathrm{NH}) ; 9.69$ $(1 \mathrm{H}, \mathrm{s}, \mathrm{NH}-\mathrm{NH}-(\mathrm{C}=\mathrm{S}) ; 9.18(1 \mathrm{H}, \mathrm{s},(\mathrm{S}=\mathrm{C})-\mathrm{NH}-\mathrm{ph})$; 7.16-7.72 (5H,m, Ar-H); 4.16 (1H,dd, CH-pyrrolidine); $3.59\left(2 \mathrm{H}, \mathrm{m}, \mathrm{CH}_{2}\right.$-pyrrolidine $) ; 2.78\left(3 \mathrm{H}, \mathrm{m}, \mathrm{CH}_{2}\right.$ and $\mathrm{CH}$-aliphatic); $1.95\left(3 \mathrm{H}, \mathrm{m}, \mathrm{CH}_{2}\right.$ and $\mathrm{CH}$-pyrrolidine); $0.99\left(3 \mathrm{H}, \mathrm{d}, \mathrm{CH}_{3}\right)$.

Compound 6: N-(4-bromophenyl)-2-((3-mercapto-2methylpropanoyl) prolyl) hydrazine-1-carbothioamide

White powder, yield 69\%, m.p: 198-200, $\mathrm{R}_{f}$ $=0.3, \mathrm{IR}\left(\mathrm{KBr}\right.$ disc, $\left.\mathrm{v}=\mathrm{Cm}^{-1}\right): 3232.7 \mathrm{br}(\mathrm{NH})$ str of $\left(1^{\text {st }}\right.$ amide, $2^{\text {nd }}$ amine and $\mathrm{NH}$ adjacent to thiocarbonyl); 2974.23, 2931.8 and $2873.94(\mathrm{C}-\mathrm{H})$ str of aliph. $\mathrm{CH}_{2}$ \& $\mathrm{CH}_{3} ; 2507.46 \mathrm{~cm}^{-1}$ str of(SH); $1685.79(\mathrm{C}=\mathrm{O}) \mathrm{str}$ of 1stamide; $1624.06(\mathrm{C}=\mathrm{O})$ str amide of pyrrolidine; 1180.44 str of $(\mathrm{C}=\mathrm{S}) ; 1068.56 \mathrm{str}$ of $(\mathrm{C}-\mathrm{Br})$. Elemental analysis: Calcd. for $\left(\mathrm{C}_{16} \mathrm{H}_{21} \mathrm{BrN}_{4} \mathrm{O}_{2} \mathrm{~S}_{2}\right) \mathrm{C}: 43.15 ; \mathrm{H}$ : 4.75; N: 12.58; S: 14.40. Found: C: 43.08; H: 4.73; N: 12.52; S: $14.29 .{ }^{1} \mathrm{HNMR}\left(500 \mathrm{MHz}, \mathrm{DMSO}_{-\mathrm{d} 6}, \delta=\mathrm{ppm}\right)$; $10.53(1 \mathrm{H}, \mathrm{s},(\mathrm{O}=\mathrm{C})-\mathrm{NH}) ; 9.92(1 \mathrm{H}, \mathrm{s}, \mathrm{NH}-\mathrm{NH}-(\mathrm{C}=\mathrm{S})$; 9.25 (1H, s, (S=C)-NH-ph); 7.69 (2H, d, 2Ar-H); 7.52 $(2 \mathrm{H}, \mathrm{d}, 2 \mathrm{Ar}-\mathrm{H}) ; 4.17$ (1H, dd, CH-pyrrolidine); 3.65 (2H, m, $\mathrm{CH}_{2}$-pyrrolidine); 2.71-3.03 $\left(3 \mathrm{H}, \mathrm{m}, \mathrm{CH}_{2}\right.$ and $\mathrm{CH}$-aliph); $1.03\left(3 \mathrm{H}, \mathrm{d}, \mathrm{CH}_{3}\right)$.

Compound 7: N-(4-chlorophenyl)-2-((3-mercapto -2-methylpropanoyl)prolyl)hydrazine-1carbothioamide

Pale white powder, yield $48 \%$, m.p: 190 192C, $\mathrm{R}_{f}=0.21, \mathrm{IR}\left(\mathrm{KBr}\right.$ disk, $\left.\mathrm{v}=\mathrm{cm}^{-1}\right): 3236.55 \mathrm{br}$ $(\mathrm{NH})$ str of ( $1^{\text {st }}$ amide, $2^{\text {nd }}$ amine and $\mathrm{NH}$ adjacent to thiocarbonyl); 2974.23, 2931.8 and 2873.94 (C-H) str of aliph. $\mathrm{CH}_{2} \& \mathrm{CH}_{3} ; 2565.33 \mathrm{~cm}^{-1}$ str of $(\mathrm{SH})$; $1685.79(\mathrm{C}=\mathrm{O})$ str of $1^{\text {st }}$ amide; $1620.21(\mathrm{C}=\mathrm{O})$ str of amide pyrrolidine; $1539.2,1492.9$ and $1462.04 \mathrm{str}$ of $\operatorname{Ar}-(C=C) ; 1176.58$ str of $(C=S) ; 1087.85$ str of $(C-C l)$. Elemental analysis: Calcd. for $\left(\mathrm{C}_{16} \mathrm{H}_{21} \mathrm{CIN}_{4} \mathrm{O}_{2} \mathrm{~S}_{2}\right) \mathrm{C}$ : 47.93; H: 5.28; N: 13.97; S: 15.99. Found: C: 47.88; $\mathrm{H}: 5.24$; N: 13.90; S: 15.81. ${ }^{1} \mathrm{HNMR}(500 \mathrm{MHz}$, DMSO- $\left._{d 6}, \delta=p p m\right) ; 10.52(1 \mathrm{H}, \mathrm{s},(\mathrm{C}=\mathrm{O})-\mathrm{NH}) ; 9.90$ $(1 \mathrm{H}, \mathrm{s}, \mathrm{NH}-\mathrm{NH}-(\mathrm{C}=\mathrm{S}) ; 9.25(1 \mathrm{H}, \mathrm{s},(\mathrm{C}=\mathrm{S})-\mathrm{NH}-\mathrm{ph})$; $7.74(2 \mathrm{H}, \mathrm{d}, 2 \mathrm{Ar}-\mathrm{H}) ; 7.39(2 \mathrm{H}, \mathrm{d}, \mathrm{Ar}-\mathrm{H}) ; 4.17(1 \mathrm{H}, \mathrm{dd}$, $\mathrm{CH}$-pyrrolidine); 3.65 (2H, m, $\mathrm{CH}_{2}$-pyrrolidine); 2.71 $3.02\left(3 \mathrm{H}, \mathrm{m}, \mathrm{CH}_{2}\right.$ and $\mathrm{CH}$-aliph.); 1.86-2.15 (4H, m, $2\left(\mathrm{CH}_{2}\right)$ - pyrrolidine; $1.035\left(3 \mathrm{H}, \mathrm{d}, \mathrm{CH}_{3}\right)$.

\section{Compound 8:2-((3-mercapto-2-methylpropanoyl)prolyl)-} N-(4-methoxyphenyl)hydrazine-1-carbothioamide

Yellow powder, yield 62\%, m.p:198-200

${ }^{\circ} \mathrm{C}, \mathrm{R}_{f}=0.33$, IR $\left(\mathrm{KBr}\right.$ disc, $\left.\mathrm{v}=\mathrm{cm}^{-1}\right): 3224.98$ $(\mathrm{N}-\mathrm{H})$ str of $\left(1^{\text {st }}\right.$ amide, $2^{\text {nd }}$ amine and $\mathrm{NH}$ adjacent to thiocarbonyl); 3124.68 Ar (C-H) str; 2974.23, 2935.66 and $2877.79(\mathrm{C}-\mathrm{H})$ str of aliph. $\mathrm{CH}_{2} \& \mathrm{CH}_{3}$; 2557.61 str of $(\mathrm{SH}) ; 1681.93(\mathrm{C}=\mathrm{O})$ str of $1^{\text {st }}$ amide; $1624.06(\mathrm{C}=\mathrm{O})$ str of amide pyrrolidine; 1543.05, 1512.19 and $1462.04 \operatorname{Ar}(\mathrm{C}=\mathrm{C})$ str; 1246 asym (C-O) str; 1180.44 str of $(C=S) ; 1029$ sym (C-O) str .Elemental analysis: Calcd. for $\left(\mathrm{C}_{17} \mathrm{H}_{24} \mathrm{~N}_{4} \mathrm{O}_{3} \mathrm{~S}_{2}\right)$ C: 51.49; H: 6.10; N: 14.13; S: 16.17. Found: C: 51.38; H: 5.97: N: 14.4; S: 15.97. 'HNMR (500MHz, DMSO- $\left._{d 6}, \delta=p p m\right) ; 10.33(1 \mathrm{H}, \mathrm{s},(\mathrm{C}=\mathrm{O})-\mathrm{NH}) ; 9.57$ $(1 \mathrm{H}, \mathrm{s}, \mathrm{NH}-\mathrm{NH}-(\mathrm{C}=\mathrm{S}) ; 9.08(1 \mathrm{H}, \mathrm{s},(\mathrm{C}=\mathrm{S})-\mathrm{NH}-\mathrm{ph})$; 7.44 (2H, d, 2Ar); $6.83(2 \mathrm{H}, \mathrm{d}, 2 \mathrm{Ar}-\mathrm{H}) ; 4.15(1 \mathrm{H}$, dd, $\mathrm{CH}$-pyrrolidine); $3.68(3 \mathrm{H}, \mathrm{s}, \mathrm{OCH} 3) ; 3.59(2 \mathrm{H}, \mathrm{m}$, $\mathrm{CH}_{2}$ pyrrolidine); $2.42-2.94\left(3 \mathrm{H}, \mathrm{m}, \mathrm{CH}_{2}\right.$ and $\mathrm{CH}$ aliph.); 1.25-2.25 (3H, m, $\mathrm{CH}_{2}$ and $\mathrm{CH}$-pyrrolidine); $0.98\left(3 \mathrm{H}, \mathrm{d}, \mathrm{CH}_{3}\right)$.

\section{Compound 9: 2-((3-(ethylthio)-2-methylpropanoyl)} prolyl)-N-phenylhydrazine-1-carbothioamide White powder, yield $49 \%$, m.p: $193-196^{\circ} \mathrm{C}$ ), $\mathrm{R}_{f}=0.47$, IR $\left(\mathrm{KBr}\right.$ disc, $\left.\mathrm{v}=\mathrm{cm}^{-1}\right): 3282.84$ overlap $(\mathrm{NH})$ str of ( $1^{\text {st }}$ amide and $2^{\text {nd }}$ amine $) ; 3244.27(\mathrm{~N}-\mathrm{H})$ str adjacent to thiocarbonyl; $3055.24 \mathrm{Ar}(\mathrm{C}-\mathrm{H})$ str; 2974.23, 2931.8 and $2873.94(\mathrm{C}-\mathrm{H})$ str of aliph. $\mathrm{CH}_{2}$ \& $\mathrm{CH}_{3} ; 1689.64(\mathrm{C}=\mathrm{O})$ str of 1 st. amide; $1654.92(\mathrm{C}=\mathrm{O})$ str of amide of pyrrolidine; 1600.92, 1546.91 and 1500.62 $\operatorname{Ar}(\mathrm{C}=\mathrm{C})$ str; 1184.29 str of $(\mathrm{C}=\mathrm{S})$. Elemental analysis: Calcd. for $\left(\mathrm{C}_{18} \mathrm{H}_{26} \mathrm{~N}_{4} \mathrm{O}_{2} \mathrm{~S}_{2}\right)$ : C: 54.79; $\mathrm{H}: 6.64$; N: 14.20; S: 16.25. Found: C: 54.70; H: 6.55; N: 13.60; S: 16.05. ${ }^{1} \mathrm{HNMR}\left(500 \mathrm{MHz}, \mathrm{DMSO}_{\mathrm{d} 6}, \delta=\mathrm{ppm}\right) ; 10.49$ $(1 \mathrm{H}, \mathrm{s},(\mathrm{O}=\mathrm{C})-\mathrm{NH}) ; 9.79$ (1H, s, NH-NH-(C=S); 9.19 (1H, s, (S=C)-NH-ph); 7.12-7.68 (5H, m, 5Ar-H); 4.18 
(1H, dd, $\mathrm{CH}$-pyrrolidine); $3.64\left(3 \mathrm{H}, \mathrm{m}, \mathrm{CH}_{2}\right.$ and $\mathrm{CH}-$ pyrrolidine); 2.71-3.02 (3H, m, $\mathrm{CH}_{2}$ and $\mathrm{CH}$-aliph.);2.09 $\left(2 \mathrm{H}, \mathrm{q}, \mathrm{CH}_{2}\right) ; 1.94\left(3 \mathrm{H}, \mathrm{t}, \mathrm{CH}_{3}\right) ; 1.03\left(3 \mathrm{H}, \mathrm{d}, \mathrm{CH}_{3}\right)$.

Compound 10: N-(4-chlorophenyl)-2-((3-(ethylthio)-2methylpropanoyl)prolyl)hydrazine-1-carbothioamide Pale white powder, yield 52\%, m.p: 202$204^{\circ} \mathrm{C}, \mathrm{R}_{f}=0.4 \mathrm{IR}\left(\mathrm{KBr}\right.$ disc, $\left.\mathrm{v}=\mathrm{cm}^{-1}\right): 3197.98$ overlap str for $(\mathrm{NH})$ of ( $1^{\text {st }}$ amide and $2^{\text {nd }}$ amine $)$; 3109.25 str for $(\mathrm{N}-\mathrm{H})$ adjacent to thiocarbonyl; 3005.1 $\operatorname{Ar}(\mathrm{C}-\mathrm{H})$ str; $2939.52(\mathrm{C}-\mathrm{H})$ str of. aliph $\mathrm{CH}_{2}$ \& $\mathrm{CH}_{3}$; $1678.07(\mathrm{C}=\mathrm{O})$ str of $1^{\text {st }}$ amide; $1631.78(\mathrm{C}=\mathrm{O})$ str of amide pyrrolidine; $1534.05,1508.33$ and 1492.90 $\operatorname{Ar}(\mathrm{C}=\mathrm{C}) \mathrm{str} ; 1192.01 \mathrm{str}$ of $(\mathrm{C}=\mathrm{S}) ; 1087.85 \mathrm{str}$ for (C-Cl). Elemental analysis: Calcd for $\left(\mathrm{C}_{18} \mathrm{H}_{25} \mathrm{CIN}_{4} \mathrm{O}_{2} \mathrm{~S}_{2}\right)$ C: $50.39 ; \mathrm{H}: 5.87$; N: 13.06; S; 14.95; Cl: 8.26. Found: C: $49.49 ; \mathrm{H}: 5.81 ; \mathrm{N}: 13.00 ; \mathrm{S}: 14.65 .{ }^{\mathrm{H}} \mathrm{HNMR}(500 \mathrm{MHz}$, DMSO- $\left._{-}, \delta=\mathrm{ppm}\right) ; 10.52(1 \mathrm{H}, \mathrm{s},(\mathrm{C}=\mathrm{O})-\mathrm{NH}) ; 9.91(1 \mathrm{H}$, s, NH-NH- $(\mathrm{C}=\mathrm{S}) ; 9.24(1 \mathrm{H}, \mathrm{s},(\mathrm{C}=\mathrm{S})-\mathrm{NH}-\mathrm{ph}) ; 7.70$ $(2 \mathrm{H}, \mathrm{d}, 2 \mathrm{Ar}-\mathrm{H}) ; 7.51(2 \mathrm{H}, \mathrm{d}, 2 \mathrm{Ar}-\mathrm{H}) ; 4.17(1 \mathrm{H}, \mathrm{dd}, \mathrm{CH}-$ pyrrolidine); $3.75\left(4 \mathrm{H}, \mathrm{m}, 2\left(\mathrm{CH}_{2}\right)\right.$ pyrrolidine); 2.71 3.38(3H, m, $\mathrm{CH}_{2}$ and $\mathrm{CH}$-aliph.); $2.09\left(2 \mathrm{H}, \mathrm{q}, \mathrm{CH}_{2}\right)$, $1.88\left(3 \mathrm{H}, \mathrm{t}, \mathrm{CH}_{3}\right) ; 1.03\left(3 \mathrm{H}, \mathrm{d}, \mathrm{CH}_{3}\right)$.

\section{Antiplatelet Activity}

The antiplatelet aggregation activity of the final synthetic CAP derivatives was measured using human plasma. Fresh blood samples were obtained from non-smoker healthy volunteers with a negative history of drug consumption, up to 14 days before the test.

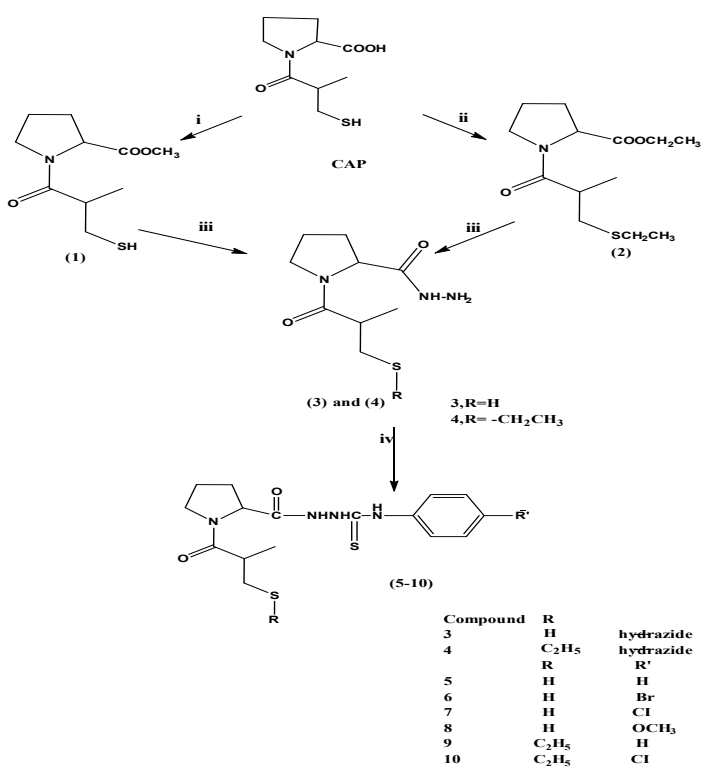

Scheme 1: Synthesis of new CAP derivatives (1-10) (i) $\mathrm{SOCl}_{2}, \mathrm{CH}_{3} \mathrm{OH}$ (ii) $\mathrm{CHCH}_{2} \mathrm{I}, \mathrm{K}_{2} \mathrm{CO}_{3},\left(\mathrm{CH}_{3}\right)_{2} \mathrm{CO}$ (iii) $\mathrm{NH}_{2} \mathrm{NH}_{2}$, $\mathrm{CH}_{3} \mathrm{CH}_{2} \mathrm{OH}$. (iv) R' PhNCS, $\mathrm{CH}_{3} \mathrm{OH}$
The whole blood was collected in sodium citrate $(9: 1)$ by volume. Specific weight of each tested compound was dissolved in (DMSO), to prepare different concentrations $(25,50,100,150$ and $200 \mu \mathrm{g}(\mathrm{ml}) .500 \mu \mathrm{l}$ of sample contains $250 \mu \mathrm{l}$ of normal saline, $125 \mu \mathrm{l}$ of whole blood, and $125 \mu \mathrm{l}$ from each concentration of tested compound was incubated for $3 \mathrm{~min}$ at $37^{\circ} \mathrm{C}$, then $5 \mu \mathrm{l}$ of (ADP) (5 $\mu \mathrm{m}), 5 \mu \mathrm{l}$ of arachidonic acid $(0.25 \mathrm{mM})$, and $1 \mu \mathrm{l}$ of collagen $(1 \mu \mathrm{g} / \mathrm{ml})$, were added separately, and aggregation was monitored for $6 \mathrm{~min}$, and area under curve (AUC) was recorded. Aspirin was used as a standard drug, and platelet aggregation inhibition percent was calculated, using Equation 1, where $\mathrm{IC}_{50}$ was calculated from first order linear equation. Equation $1^{25}$ :

$\%$ Inhibition $=[1-(\mathrm{D} / \mathrm{S})]{ }^{*} 100$

Where D: platelet aggregation in the presence of a tested compound, S: platelet aggregation in the presence of a solvent.

\section{Docking Study}

Molecular docking is an attractive scaffold of computational modelling, which facilitates the prediction of preferred binding orientation of one molecule to another, as well as, help in the mechanistic study by placing a molecule (ligand) into the preferred binding site of the target specific region of the DNA/protein (receptor), mainly in a non-covalent fashion, to form a stable complex of potential efficacy and more specificity when both interact with each other, in order to form a stable complex. ${ }^{26,27}$

Computer stimulation automated docking study was performed using molecular docking software, Pymol Autodock/vina plugin. The crystallography structure of purino receptor $\mathrm{P}_{2} \mathrm{Y}_{12}$, cyclooxygenase-1 (COX-1), and glycoprotein $\mathrm{ll} / \mathrm{b} / \mathrm{ll}$ la proteins were taken from (PDB) with resolution 1.45, 2.61 and $2.45 \mathrm{~A}^{\circ}$ and PDB ID (4XPZ, 1EQG, and 3ZDY), respectively. The target proteins were prepared for docking study using VC5F chimera version 1.11.2 software, where all bonded ligands, water molecules were removed from it.

Gauss view 6.0 software was used for building the $3 \mathrm{D}$ structure of starting and designed derivatives and for optimization the energy for flexible 
docking. The binding affinity, ordering ligand and inhibition constant (Ki) were performed using pymol Auto dock/ vina plugin, while the type of amino acid in the target protein that involved in the formation of $\mathrm{H}$-bond, and its number, was predicted using Auto dock-tools 1.5.6.

\section{RESULTS AND DISCUSSION}

\section{Chemistry}

Methyl ester 1 obtained by adding an equal mmole of thionyl chloride to ice solution of captopril in absolute methanol, raise the temperature of the reaction mixture to catalyze the reaction. Compound 1 characterized by IR spectroscopy, due to the absence of broad $\mathrm{OH}$ band, and carbonyl band of CAP carboxylic acid, and appearance of a peak of $(\mathrm{C}=\mathrm{O})$ ester str, at $1732 \mathrm{~cm}^{-1}$.

Ethyl ester 2 obtained from reaction of two mmoles of ethyl iodide with CAP solution, in dry acetone, for esterification of carboxylic acid group, and ethyl alkylation of the thiol group (SH), in the presence of anhydrous $\mathrm{K}_{2} \mathrm{CO}_{3}$, as a catalyst. The absence of $(\mathrm{SH})$ peak at $2565 \mathrm{~cm}^{-1}$ and appearance of $(\mathrm{C}=\mathrm{O})$ ester peak at $1728.22 \mathrm{~cm}^{-1}$, are the main IR characterization.

Compounds 3 and 4 are prepared by refluxing a solution of compounds 1 or 2 in dry EtOH with hydrazine hydrate for $2 \mathrm{~h}$, respectively. The IR spectrum characterized by a band of hydrazide primary amine at 3506, 3460 and $3305,3213 \mathrm{~cm}$ -1 for 3 and 4 , respectively, with a distinct peak for $(\mathrm{C}=\mathrm{O}) \mathrm{str}$. of an amide of hydrazide at $1662 \mathrm{~cm}^{-1}$ and $1693.3 \mathrm{~cm}^{-1}$, respectively.

Thiosemicarbazide derivatives of CAP (5-10) were synthesized by stirring a warm solution of compounds 3 or 4 with the corresponding substituted phenyl isothiocyanate derivatives.

IR spectra of (5-10), each displayed distinct broad band at $3248,3232,3236,3224,3282$, and 3197 , respectively, indicating overlap of three $(\mathrm{NH})$ bands.

${ }^{1}$ HNMR spectroscopy displayed characteristic signals for the prepared compounds. Compound 1 showed a distinct singlet peak at $\delta=$ 3.55.ppm due to $\left(\mathrm{OCH}_{3}\right)$ str, an (indication of methyl ester formation). Hydrazide compound 3 , displayed in ${ }^{1} \mathrm{HNMR}$ spectrum a singlet peak, at $\delta=9.22$ and $\delta=8.91 \mathrm{ppm}$ due to major and minor $\mathrm{NH}$ group, also another significant peak at $\delta=4.21 \mathrm{ppm}$, as abroad singlet, due to appearance $\mathrm{NH}_{2}$ of hydrazide.

While compound 4 , using $\mathrm{CD}_{3} \mathrm{OD}$ as a solvent, recorded a peak as a multiplet at $\delta=2.55$ $3.20 \mathrm{ppm}$ integrating for five protons, due to two aliphatic $\left(\mathrm{CH}_{2}\right)$ and one $(\mathrm{CH})$ groups, another significant peak at $\delta=1.19-1.25 \mathrm{ppm}$, integrating for six protons owing to two aliphatic methyl groups $\left(2 \mathrm{CH}_{3}\right)$.

Compounds (5-8), each displayed three prominent signals, attributed to three $\mathrm{NH}$ groups of the thiosemicarbazide derivatives, as follow: $(\mathrm{C}=\mathrm{O})$ $\mathrm{NH}, \mathrm{NHNH}-(\mathrm{C}=\mathrm{S})$ and $(\mathrm{C}=\mathrm{S})-\mathrm{NH}-\mathrm{ph}$ : at $\delta=10.38$, 9.69, 9,18 for compound $5 ; \delta=10.53,9.92,9.25$ for compound 6 ; $\delta=10.52,9.90,9.25$ for compound 7 ; and $\delta=10.33,9.57$, and $9.08 \mathrm{ppm}$ for compound 8 , respectively.

Also, compounds (9 \&10), each recorded the following signals for the three $\mathrm{NH}$ groups at $\delta=$ $10.49,9.79,9.19$ for compound 9 and 10.52, 9.91 and $9.24 \mathrm{ppm}$ for compound 10 .

In addition, the S-ethylation group ( $\mathrm{S}-\mathrm{CH}_{2}-$ $\mathrm{CH}_{3}{ }^{-}$) of each protected (SH), displayed obviously, for compound $9,\left(\mathrm{CH}_{3}\right)$ recorded as a triplet at $\delta=$ $1.94 \mathrm{ppm}$, and at $\delta=2.09 \mathrm{ppm}$, as a quartet for $\left(\mathrm{CH}_{2}\right)$ group, while compound 10 showed a signal at $\delta=$ $1.88 \mathrm{ppm}$, as a triplet, due to $\left(\mathrm{CH}_{3}\right)$, and at $\delta=2.09$ ppm, as a quartet due to $\left(\mathrm{CH}_{2}\right)$, respectively.

All the aromatic protons for the compounds (5-10) displayed at their expected aromatic region (see exp. part).

\section{Antiplatelet Activity}

The in- vitro antiplatelet activity of all final derivatives was assayed on whole human blood using Multiplate ${ }^{\circledR}$ analyzer. Adenosine diphosphate (ADP), arachidonic acid (AA), and collagen were used as inducers for platelet aggregation, where aspirin was used as positive control. The $\mathrm{IC}_{50}$ was defined as the concentration of the test compound that inhibits platelet aggregation by 50 percent. 
The antiplatelet activity of tested compounds is listed in (Table 1). Data shows that the majority of derivatives inhibit platelet aggregation induced by arachidonic acid and collagen greater than that induced by ADP. Among tested compounds, derivative 7 and 10 were more potent inhibitor of platelet aggregation induced by arachidonic acid with $\%$ inhibition $(97.14 \pm 0)$ and $\%(95.71 \pm 2.02)$, and $\mathrm{IC}_{50}$ (2.7 and $1.217 \mu \mathrm{glml}$ ), respectively, and compound 6 and 10 , showed better antiplatelet activity induced by collagen with \% inhibition $(83.9 \pm 2.8$ and $78.5 \pm 1.44)$ and $\mathrm{IC}_{50}(5.27$ and $0.817 \mu \mathrm{g} / \mathrm{ml})$, respectively. Based on these results, it could be suggested that phenyl substitution with electron withdrawal group (EWG) enhances the antiplatelet activity of a synthetic compound in a better manner than unsubstituted, or phenyl substituted with electron donating group (EDG). However, the activity of all synthetic derivatives are still better than that of a parent (captopril), that means, chemical replacement of carboxylic acid of captopril with thiosemicarbazide moiety could enhance antiplatelet activity, while the modification on thiol group, has a little effect.

Table1: Percent inhibition \pm SD and $I C_{50}$ of tested compounds (5-10), using ADP, AA, and collagen as inducer agents

\begin{tabular}{|c|c|c|c|c|c|c|}
\hline Compound & $\begin{array}{c}\text { ADP } \\
\% I N H \pm S D\end{array}$ & $\mathrm{IC}_{50} \mu \mathrm{g} \backslash \mathrm{ml}$ & $\begin{array}{c}\mathrm{AA} \\
\% \mathrm{INH} \pm \mathrm{SD}\end{array}$ & $\mathrm{IC}_{50} \mu \mathrm{g} \backslash \mathrm{ml}$ & $\begin{array}{l}\text { Collagen } \\
\% I N H \pm S D\end{array}$ & $\mathrm{IC}_{50} \mu \mathrm{g} \backslash \mathrm{ml}$ \\
\hline 5 & $42.23 \pm 0$ & 259.08 & $88.5 \pm 0$ & 57.98 & $73.46 \pm 0$ & 26.6 \\
\hline 6 & $49.4 \pm 0$ & 209.67 & $91.4 \pm 4.04$ & 15.8 & $83.9 \pm 2.8$ & 5.27 \\
\hline 7 & $40.588 \pm 0.88$ & 283.15 & $97.14 \pm 0.0$ & 2.7 & $70.4 \pm 1.44$ & 9.6 \\
\hline 8 & $45.88 \pm 0$ & 218.17 & $92.85 \pm 2.02$ & 16.01 & $76.5 \pm 1.44$ & 10.6 \\
\hline 9 & $17.64 \pm 0$ & $569.1 \mu \mathrm{g} \backslash \mathrm{ml}$ & $81.42 \pm 2.02$ & 81.89 & $37.75 \pm 1.44$ & 281.19 \\
\hline 10 & $39.41 \pm 0.83$ & $257.52 \mu \mathrm{g} \backslash \mathrm{ml}$ & $95.71 \pm 2.02$ & 1.217 & $78.5 \pm 1.44$ & 0.817 \\
\hline Captopril & $41.1 \pm 0.0$ & 266.107 & $75.71 \pm 2.02$ & 16.04 & $50 \pm 1.44$ & 199.7 \\
\hline Aspirin & $35.88 \pm 0.83$ & 326.5 & $85.71 \pm 0$ & 21.73 & $28.57 \pm 0.0$ & 388.23 \\
\hline
\end{tabular}

ADP: Adenosine diphosphate; AA: Arachidonic acid; \% INH: Inhibition percent, which calculated as an average of three values of AUC for each concentration; SD: Standard deviation; $\mathrm{IC}_{50}$ : The half maximum inhibitory concentration.

\section{Docking Study}

Generally, the docking study was performed to determine the binding score that helps in the prediction of the activity of synthesized derivatives. Several proteins play a role in regulating platelet aggregation, among them purino receptor: $P_{2} Y_{12}$, COX-1 and glycoprotein Ilb/llla that play a vital role, where ADP, arachidonic acid, and collagen act as agonist respectively. The affinity of tested compounds against purinoreceptor $\mathrm{P}_{2} \mathrm{Y}_{12}$ : were $8>6>$ captopril $>10>5>7>9>$ aspirin, and the affinity of tested compounds against COX-1 was: $7>10>8>$ $6>5>9>$ captopril $>$ aspirin, while the sequence of compounds against glycoprotein IIb/llla was $7>6>$ $8>5>10>9>$ captopril> aspirin according to binding energy values as shown in (Table 2), compound with lower energy value, predicted to has higher activity.

Table 2: Docking study of tested compounds (5-10)

\begin{tabular}{|c|c|c|c|c|c|c|c|c|c|}
\hline \multirow[t]{2}{*}{ Enzyme } & & \multicolumn{8}{|c|}{ Tested CAP derivatives $(5-10)$} \\
\hline & & CAP. & Asp. & 5 & 6 & 7 & 8 & 9 & 10 \\
\hline \multirow[t]{3}{*}{$4 X P Z$} & $\begin{array}{l}\text { Binding energy } \\
\text { (Kcal)/ mol }\end{array}$ & -6.57 & -0.7 & -5.73 & -7.94 & -5.4 & -8.21 & -4.03 & -6.55 \\
\hline & $\mathrm{Ki}(\mu \mathrm{M})$ & 15.25 & 0.304 & 63.44 & 1.54 & 109.45 & 0.952 & 1.02 & 0.956 \\
\hline & $\begin{array}{c}\text { H-bond } \\
\text { Amino acid }\end{array}$ & $\begin{array}{c}2 \\
\text { TYR 209, } \\
\text { ASN 235 }\end{array}$ & 0 & 0 & 0 & 0 & 0 & 0 & 0 \\
\hline \multirow[t]{4}{*}{ 1EQG } & $\begin{array}{l}\text { Binding energy } \\
(\text { Kcal }) / \mathrm{mol}\end{array}$ & -6.84 & -6.8 & -8 & -8.34 & -10.67 & -10.33 & -7.86 & -10.66 \\
\hline & $\mathrm{Ki}(\mathrm{Mm})$ & 9.68 & 10.314 & 1.38 & 0.773 & 0.0512 & 0.0266 & 1.74 & 0.0207 \\
\hline & $\begin{array}{l}\text { H-bond } \\
\text { Amino }\end{array}$ & 1 & 2 & 0 & 2 & 2 & 1 & 1 & 2 \\
\hline & acid & $\begin{array}{l}\text { SER530 } \\
\text { TRP387 }\end{array}$ & $\begin{array}{l}\text { THR206, } \\
\text { ASN382 }\end{array}$ & & $\begin{array}{l}\text { HIS207, } \\
\text { TYR } 355\end{array}$ & ARG 120, & THR206 & $\begin{array}{l}\text { THR206 } \\
\text { TYR355 }\end{array}$ & $\begin{array}{l}\text { ARG } \\
120\end{array}$ \\
\hline \multirow[t]{3}{*}{ 3ZDY } & $\begin{array}{l}\text { Binding energy } \\
\text { (Kcal)/ mol }\end{array}$ & -4.8 & 0.1 & -9.19 & -10.05 & -10.41 & -9.74 & -6.64 & -8.49 \\
\hline & $\mathrm{Ki}(\mu \mathrm{M})$ & 131.944 & & 0.184 & 0.042 & 0.023 & 0.0723 & 12.94 & 1.33 \\
\hline & $\begin{array}{c}\mathrm{H} \text {-bond } \\
\text { Amino acid }\end{array}$ & $\begin{array}{c}1 \\
\text { ALA122 }\end{array}$ & 0 & $\begin{array}{c}1 \\
\text { ASP126 }\end{array}$ & $\begin{array}{c}2 \\
\text { ARG B214, } \\
\text { ASP A224 }\end{array}$ & 0 & 0 & $\begin{array}{c}0 \\
\text { ARG B214, } \\
\text { ARG B216 }\end{array}$ & 2 \\
\hline
\end{tabular}


CAP: Captopril; ASP: Aspirin; (4XPZ, 1EQG, and 3ZDY) are PDB ID of purino receptor $\mathrm{P}_{2} \mathrm{Y}_{12}$, cyclooxygenase-1 (COX-1), and glycoprotein Ilb/Illa respectively; Ki: inhibition constant; TYR:

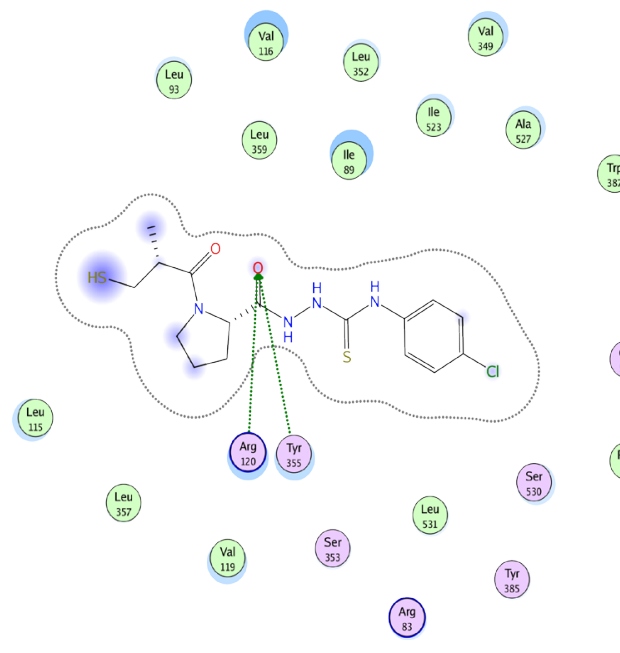

(a)

Fig. 3. Compound 7, binding to $1 \mathrm{EQG}$

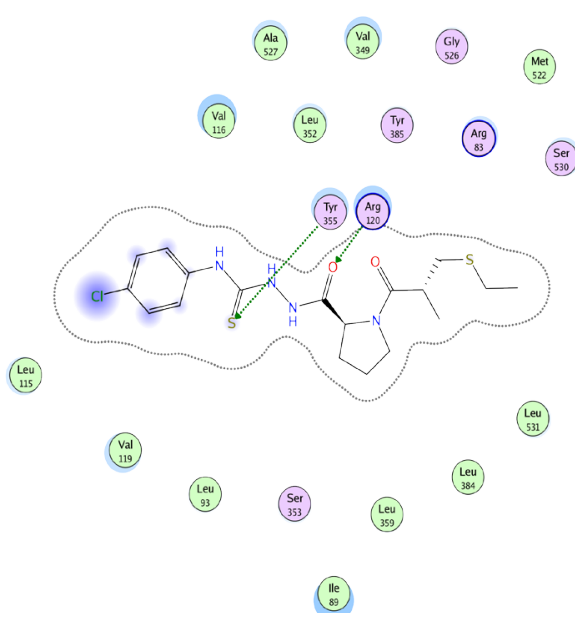

(b)

Fig. 4. Compound 10, binding to $1 E Q G$

\section{CONCLUSION}

New thiosemicarbazide derivatives of captopril have been successfully synthesized and characterized. Most CAP thiosemicarbazide derivatives displayed moderate antiplatelet activity through a COX-1 inhibitor pathway, and compound 10 was the best one, with lower $\mathrm{IC}_{50}$. The tested compounds, like 6, also showed antiplatelet activity through glycoprotein IIb/IIla receptor inhibitor pathway, but lower than that of COX-1, however,
Tyrosine; ASN: Asparagine; SER: Serine; THR: Threonine; TRP: Tryptophan; HIS: Histidine; ARG: Arginine; ALA: Alanine; ASP: Aspartic acid.

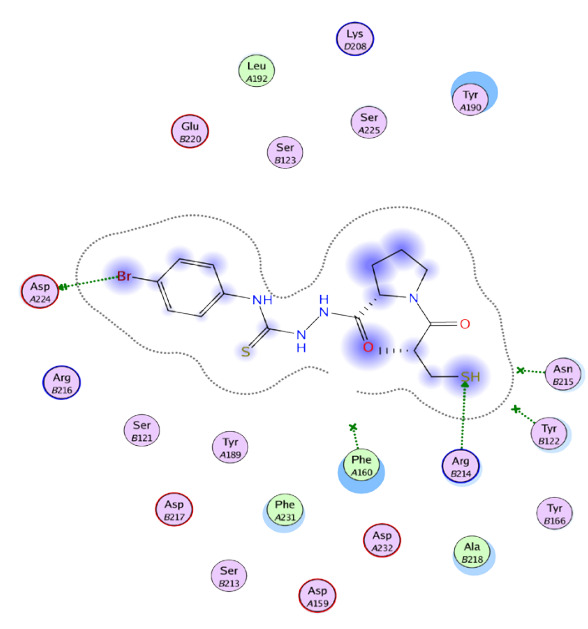

(c)

Fig. 5. Compound 6, binding to 3ZDY

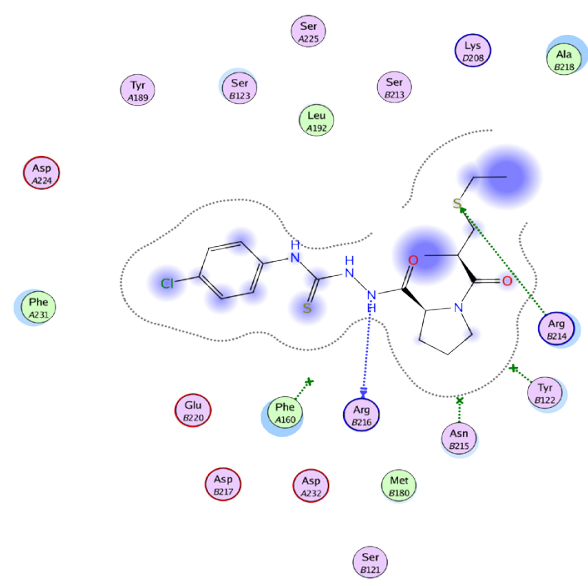

(d)

Fig. 6. Compound 10, binding to 3ZDY

the (glycoprotein) pathway, may be considered as a second pathway.

\section{ACKNOWLEDGMENT}

We're grateful to Bayan Group, for Advance Lab Diagnostics in Basrah-Iraq, for their support in accomplishment the antiplatelet activity. Also many thanks and appreciation to Dr. Abdulrahman Mohammed Saleh; Medicinal chemistry and drug design, M.Sc student at Faculty of Pharmacy for Boys - Al-Azhar University/Cairo-Egypt, Email: abdo. 
saleh240@gmail.com; / biomol.center@gmail.com, for providing necessary docking data.

\section{CONFLICT OF INTEREST}

All authors have none to declare

\section{REFERENCES}

1. Sathyapriya, E.; Velpandian, V.; Anbu J.; Anjana, A., In-vitro antiplatelet aggregation activity and thrombolytic activity of Cheenalinga Chendhuram. Inter. J.life Sci. Pharm. Res., 2012, 2(4), 51-55.

2. Rivera, J.; Lozano, M.L.; Navarro, L.; Vicente, V., Platelet receptors and signaling in the dynamics of thrombus formation. Haematologica., 2009, 94(5), 701-711.

3. Rasche, H., Haemostasis and thrombosis: an overview. Eur. Heart J. Supp., 2001, 3, 3-7.

4. Roma, G.; Di Braccio, M.; Grossi, G.; Piras, D.; Leoncini, G.; Bruzzese, D., Synthesis and in -vitro antiplatelet activity of new 4-(1-piperazinyl) coumarin derivatives. Human platelet phosphodiesterase 3 inhibitory properties of the two most effective compounds described and molecular modeling study on their interactions with phosphodiesterase 3A catalytic site. J. Med. Chem., 2007, 50(12), 2886-2895.

5. Khalid, W.; Badshah, A.; Khan, A.; Nadeem, H.; Ahmed, S., Synthesis, characterization, molecular docking evaluation, antiplatelet and anticoagulant actions of 1, 2, 4 triazole hydrazone and sulphonamide novel derivatives. Chem. Cen. J., 2018,12(1), 1-16.

6. Lee, W.; Yoo, H.; Ku, S.; Kim, J.A.; Bae, J.S., Anticoagulant activities of piperlonguminine in- vitro and in-vivo. BMB reports., 2013, 46(10), 484-489.

7. Pawar, D.; Shahani, S.; Maroli, S., Aspirin-the novel antiplatelet drug. Hong Kong Med. J., 1998, 415-418.

8. Zhang, P. X. ; Lin, H. Qu, C.; Tang, Y.P.; Li, N.G.; Kai, J., Design, synthesis, and in-vitro antiplatelet aggregation activities of ferulic acid derivatives. J. Chem., 2015, 2015,1-7.

9. Amin, A. M.; Sheau, C. L.; Azri, M. N.; Kader, S.A.; Ali, M.; Kah, H. Y., The personalization of clopidogrel antiplatelet therapy: the role of integrative pharmacogenetics and pharmaco metabolomics. Card. Res. Pra., 2017, 3(7), 1-17.

10. Kim, S.; Choi, J.H.; Kang, M.; Cha, J.K.; Huh, J.T., Safety, and efficacy of intravenous tirofiban as antiplatelet premedication for stent-assisted coiling in acutely ruptured intracranial aneurysms. Ame. J. Neur., 2016, 37(3), 508-514.

11. Pishawikar, S.A.; More, H.N., Synthesis of mannich bases of thiosemicarbazide as mutual prodrug and in-vitro screening for anti-infective activity. Int. J. Pharm. Sci. Rev. Res., 2013, 20(2), 210-214.

12. Mentese, E.; Yılmaz, F.; Baltas, N.; Bekircan, O.; Kahveci, B., Synthesis and antioxidant activities of some new tri-heterocyclic compounds containing benzimidazole, thiophene, and 1, 2, 4-triazole rings. J. Enz. Inh. Med. Chem., 2015, 30(3), 435-441.

13. He, J.; Wang, X.; Zhao, X.; Liang, Y.; He, H.; Fu, L., Synthesis and antitumor activity of novel quinazoline derivatives containing thiosemicarbazide moiety. Eur. J. Med. Chem., 2012, 54, 925-930.

14. Kumar, R.S.; Idhayadhulla, A.; Nasser, A.; Kavimani, S.; Indumathy, S., Synthesis and anticonvulsant activity of a new series of 1 , 4-dihydropyridine derivatives. Ind. J. Pharm. Sci., 2010, 72(6), 719-725.

15. Lima, L. M.; Ormelli, C.B.; Fraga, C.A.; Miranda, A.L.; Barreiro, E. J. New antithrombotic aryl-sulfonyl thiosemicarbazide derivatives synthesized from natural safrole. J. Brazi. Chem. Soc., 1999, 10(5), 421-428.

16. Dovizio, M.; Alberti, S.; Sacco, A.; Guillem, L.; Schiavone, S.; Maier, T.J., Novel insights into the regulation of cyclooxygenase-2 expression by platelet-cancer cell cross-talk. Bio. Soc.Trans., 2015, 43(4), 707-714.

17. Faisal, M.; Dawood, A.; Hussein, A., Design, synthesis and preliminary pharmacological evaluation of mutual prodrug of non-steroidal anti-inflammatory drugs coupling with natural anti-oxidants via lycine. AJPS., 2013, 13(1), 155-169.

18. Sharma N, Synthesis, characterization \& biological evaluation of mutual prodrugs of some selected NSAIDs conjugated with different antioxidant via different amino acids. Org. Med. Chem. I. J., 2017, 4(4), 1-5. 
19. Khurana, J.M.; Sahoo, P.K., Chemoselective alkylation of thiols: A detailed investigation of reactions of thiols with halides. Synth Commun., 1992, 22(12), 1691-1702.

20. Chau, K.D.; Duus, F.; Le, T.N., Methyl esterification of carboxylic acids with dimethyl carbonate promoted by $\mathrm{K}_{2} \mathrm{CO}_{3}$ / tetrabutylammonium chloride. Gr. Chem. Let. Rev., 2013, 6(1):89-93.

21. Azarmidokht, G.S.; Christian, R. Alkylation of carboxylic acids in a microfluidic device: kinetics parameters determination, Hammett reaction constant measurement and optimization of preparative experiment. $13^{\text {rd }}$ Inter. Elec. Conf. Syn. Org. Chem., 2009, 1(30), 1-14.

22. Kokila, P.; Rinku, P.; Sejal, J.; Rekha, P. Efficient synthesis and biological evaluation of 3-(phenyl)-6-(4-aminophenyl)[1,2,4] triazolo[3,4- b][1,3,4] thiadiazole and their Schiff base derivatives. Inter. J. Chem.Tech. Res., 2011, 3(2), 761-765.
23. Mansur, N.; Koopaeia, M.; Ali, A.; Seyedeh, F.; Ghasem, N.; Mohsen, A.; AKb, N.; Nassiri, K.; Maryam, G.; Arash, T., Synthesis and analgesic activity of novel hydrazide and hydrazine derivatives. Iran. J. Pharm. Res., 2013, 12(4), 721-727.

24. Hui, W.; Yulan, Z.; Youhong, H.; Shaozu, W., Synthesis of 5-ferrocenyl-4-phenyl-4H-1,2,4triazole-3-thiol and its derivatives. Syn. Reac. Inorg. Met. Org. Chem., 1994, 24(7), 11211125.

25. Eskandariyan, Z.; Zadeh, M.E.; Tehrani, K.; Mashayekhi, V.; Kobarfard, F., Synthesis of thioether derivatives of quinazoline-4-one2-thione and evaluation of their antiplatelet aggregation activity. Arch. Pharm. Res., 2014, 37(3), 332-339.

26. Mukesh, B.; Rakesh, K., Molecular docking: A review. Int. J. Res. Ayur. Pharm., 2011, 2, 1746-1751.

27. Guedes, I.A.; de Magalhães, C.S.; Dardenne, L.E., Receptor-ligand molecular docking. Biophys. Rev., 2014, 6(1), 75-87. 